Д-р техн. наук Т.В. Бутько, М.С. Бабіля

\title{
ФОРМАЛІЗАЦІЯ ПРОЦЕСІВ ДЕКОМПОЗИЦІЇ ВХІДНОГО ПОТОКУ ВАГОНІВ НА ПРИКОРДОННИХ СТАНЦІЯХ
}

Актуальність. Високорозвинена транспортна система кожної держави $\epsilon$ гарантом іï економічного зростання. Вигідне географічне розташування України забезпечило проходження п'яти міжнародних транспортних коридорів (МТК) по іiі території, що стало першим 
кроком на шляху інтеграції національних транспортних систем до світової системи.

Очікуване збільшення обсягів міжнародних вантажопотоків створює великий потенціал для ринку транспортних послуг вже найближчим часом. Але подальший розвиток МТК неможливий без вирішення проблеми забезпечення скорочення часу доставки вантажів.

На даний час ЄС хоче лібералізувати свій залізничний сектор, щоб збільшити використання залізничного транспорту. Нові оператори поїздів повинні мати можливість розвивати ефективну, новаторську та стійку господарську діяльність. Ключовою умовою для такої лібералізації $є$ експлуатаційна сумісність залізничних систем ЄС. Для інтеграції України у залізничну структуру, яка формує Транс'європейську транспортну мережу ТЄМ-Т, має бути вирішено i питання реалізації Концепції Інтероперабельності.

Таким чином, формування логістичних технологій роботи прикордонних станцій 3 передавання вантажних вагонів 3 колії 1435 мм на колію 1520 мм та у зворотному напрямку, $\epsilon$ актуальним науково-прикладним завданням.

Аналіз попередніх досліджень. Вагомий несок у розбудову теорії удосконалення технології роботи прикордонних передавальних та перевантажувальних станцій зробили у різні часи такі визначні вчені та фахівці залізничного транспорту: Акулінічев В.М., $\quad$ Альошинський Є.С., Бутько T.B., Данько M.I., Кірпа Г.М., Босов А.А., Вєтухов С.А., Ломотько Д.В., Прохорченко А.В. тощо, а також нове покоління дослідників в особах Бауліної Г.С., Іванової Т.В., Кіхтєвої Ю.В., Обухової А.Л., Титова М.Ф. та ін.

Роботи і дослідження вчених були спрямовані на вирішення завдання скорочення часу простою вагонів на передавальних та перевантажувальних станціях. Найбільша увага при розгляді можливих шляхів удосконалення процесу міждержавних вантажних перевезень та функціонування

прикордонних

передавальних сортувальних залізничних станцій приділялась удосконаленню роботи технічних засобів та розрахункам відповідних витрат ресурсів.

Викладення основного матеріалу. Одним 3 важливих питань удосконалення технології перетинання міждержавних кордонів $\epsilon$ дослідження особливості вхідного вагонопотоку. 3 метою вирішення завдання формування математичної моделі процесів декомпозиції вхідного потоку вагонів на станціях стикування колій різної ширини (ССКРШ), яка б дозволяла визначати вартісні та часові параметри та дала можливість запроваджувати логістичні технології обслуговування вагонопотоків, засновані на узгодженості використання наявних матеріальних та грошових ресурсів, проаналізуємо існуючі технології передавання вагонопотоків 3 колії однієї ширини на колію іншої ширини.

Для подальшого дослідження прийняті такі способи обслуговування вагонопотоків на ССКРШ: перевантаження вантажів у парку перевантаження (ППер), зміна візків вагонів у пункті перестановки візків (ППВ) та зміна відстані між гребенями коліс за допомогою колієперевідного пристрою SUW-2000 у пункті розсування колісних пар (ПРКП), але кожен з цих способів має свої переваги та недоліки [1].

Основним у сучасних умовах є спосіб перевантаження вантажів 3 вагонів однієї колії у вагони іншої колії. Його головною перевагою є зменшення плати за вагони іноземних залізниць, що знаходяться на українських залізницях. До недоліків можна віднести збільшення простою вагонів під вантажними операціями, необхідність у наявності комплексу складів i вантажнорозвантажувальних механізмів, необхідність у кріпленні вантажів, що перевозяться на відкритому рухомому складі. 
Виконання ряду операцій за цією технологією накладає особливі специфічні вимоги як на технічні пристрої перевантажувальної станції, так i на характер її роботи:

1) перевантаження вантажів виконується в більшості випадків безпосередньо з вагона однієї колії у вагон іншої колії і вимагає:

- строгого узгодження підходу навантажених і порожніх вагонів по обох коліях з метою скорочення простою вагонів в очікуванні;

- спеціального підбору вагонів різної ширини колії в групи рівної вантажопідйомності та за родами вантажів;

2) колієвий розвиток складається 3 двох комплектів - колій і парків колій шириною 1435 мм і 1520 мм;

3) пункти перевантаження спеціалізуються за родами вантажів i вагонів i обладнуються засобами механізації і коліями для вагонів різної ширини колій;

4) на прикордонних станціях колії 1520 мм перетинаються із коліями шириною колії 1435 мм в одному рівні, що утворює глухі схрещення, а це значно збільшує ворожість при маневрових пересуваннях $\mathrm{i}$ ускладнює маневрову роботу.
Ураховуючи

функціонування особливості прикордонних перевантажувальних станцій, необхідно зазначити, що для виконання перелічених вище операцій, а також операцій 3 передавання рухомого складу, виконання митного, прикордонного оглядів і т.д., ці станції повинні мати відповідні пункти, службово-технічні будинки й інші пристрої.

Таким чином, можна скласти принципову схему станції, де передбачено розміщення ППВ (пункту перестановки візків), ПРКП (пункту розсування колісних пар) та ППер (парку перевантаження) (див. рис. 1).

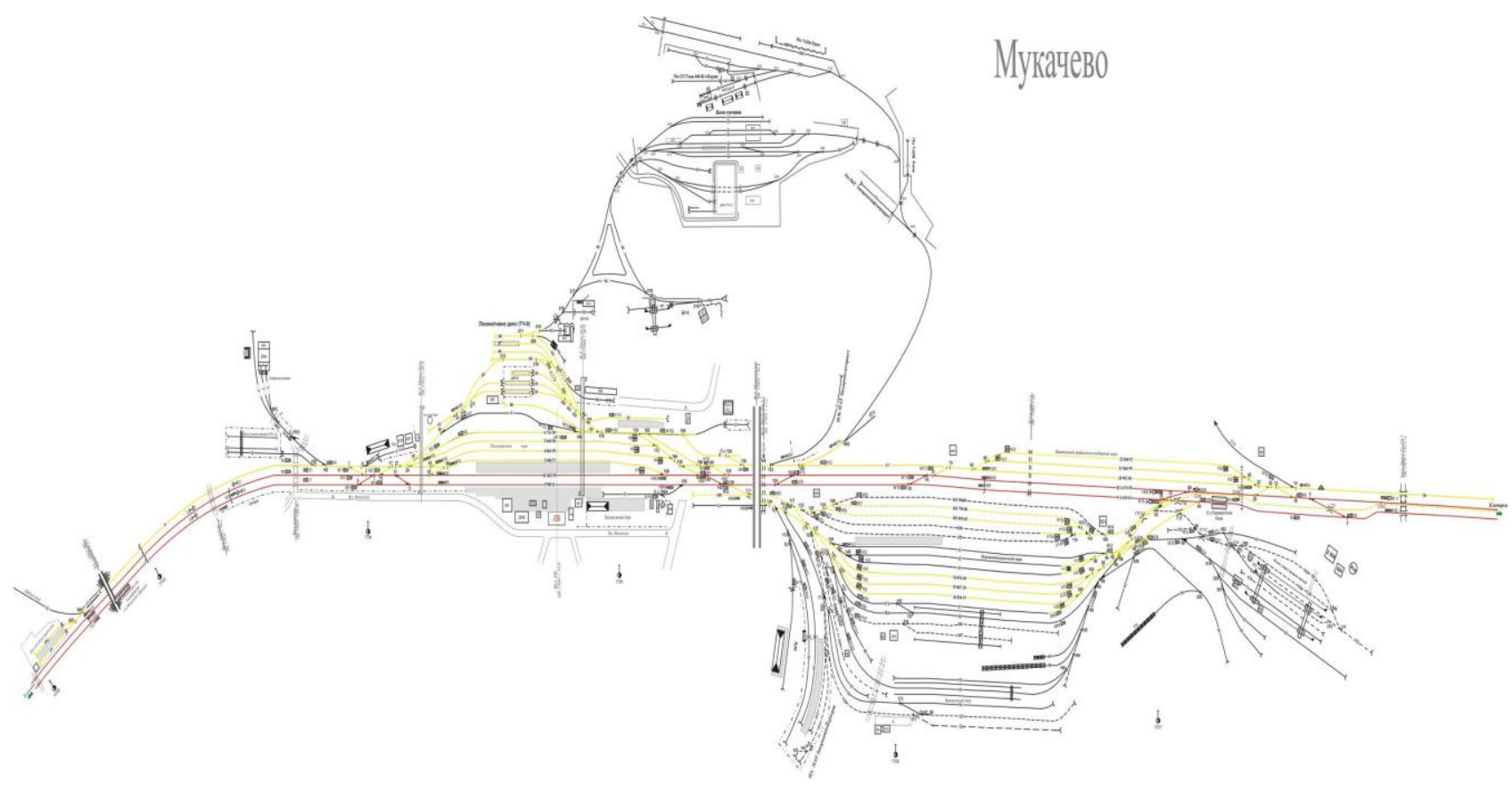

Рис. 1. Принципова схема станції Мукачево

Дана станція є лише окремою ланкою логістичної системи (ЛС) доставки вантажів міжнародного призначення, що показана у спрощеному вигляді на рис. 2 . Для даної логістичної системи термін доставки $\mathrm{T}_{\text {д }}$ визначається таким чином: 


$$
T_{\text {д }}=\sum_{1}^{k} \boldsymbol{t}_{3}+\sum_{1}^{m} \boldsymbol{t}_{T}^{\prime}+\sum_{1}^{l} \boldsymbol{t}_{\text {відпр }}+\sum_{1}^{p} \boldsymbol{t}_{1520}+\sum_{1}^{s} \boldsymbol{t}_{\text {nер }}+\sum_{1}^{c} \boldsymbol{t}_{1435}+\sum_{1}^{x} \boldsymbol{t}_{\text {призн }}+\sum_{1}^{g} \boldsymbol{t}_{T}^{\prime \prime}+\sum_{1}^{z} \boldsymbol{t}_{\Pi} .
$$

де $\sum_{1}^{k} t_{3}, \sum_{1}^{z} t_{n}$ - сума простоїв продукції у пунктах зародження та погашення вантажопотоків;

$$
\sum_{1}^{m} t_{T}^{\prime}, \sum_{1}^{g} t_{T}^{\prime \prime} \text { - сумарний час доставки }
$$

вантажу від складу вантажовідправника до станції призначення та від станції призначення до складу вантажоодержувача; $\sum_{1}^{l} \boldsymbol{t}_{\text {відnp }}, \sum_{1}^{s} \boldsymbol{t}_{\text {nеp }}, \sum_{1}^{x} \boldsymbol{t}_{\text {призн }}$ - сумарний час перебування вантажу на станціях відправлення, перевантаження та призначення;

$$
\sum_{1}^{p} t_{1520}, \quad \sum_{1}^{c} t_{1435}-\text { сумарний час }
$$
транспортування вантажів у вагонах широкої та вузької колії відповідно.

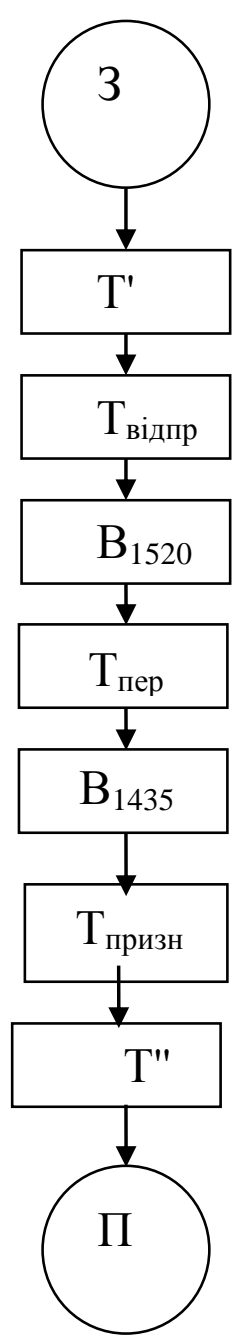

Умовні позначення:

3 - місце зародження вагонопотоку (склад вантажовідправника);

T' - транспортування від вантажовідправника до станції відправлення;

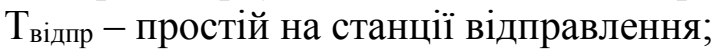

$\mathrm{B}_{1520}$ - просування вантажу у вагонах колії 1435 мм;

$\mathrm{T}_{\text {пер }}$ - простій на прикордонній перевантажувальній станції;

В 1435 - просування вантажу у вагонах колії 1435 мм;

$\mathrm{T}_{\text {призн }}-$ простій на станції призначення;

T" - транспортування від станції призначення до вантажоодержувача;

П - місце погашення вагонопотоку (склад вантажоодержувача).

Рис. 2. Спрощена схема доставки вантажів міжнародного призначення

Оскільки термін доставки вантажів визначається як сума часових характе- ристик усіх ланок логістичного ланцюга [2], то буде доцільним проаналізувати час 
перебування вантажних вагонів на ССКРШ 3 метою визначення основних критеріїв, що впливають на цей час.

Станції стикування колій різної ширини необхідно розглядати як вагому ланку у ланцюжку доставки вантажів міжнародного призначення від відправника до одержувача [3], яка визначає часову складову усієї ЛС.

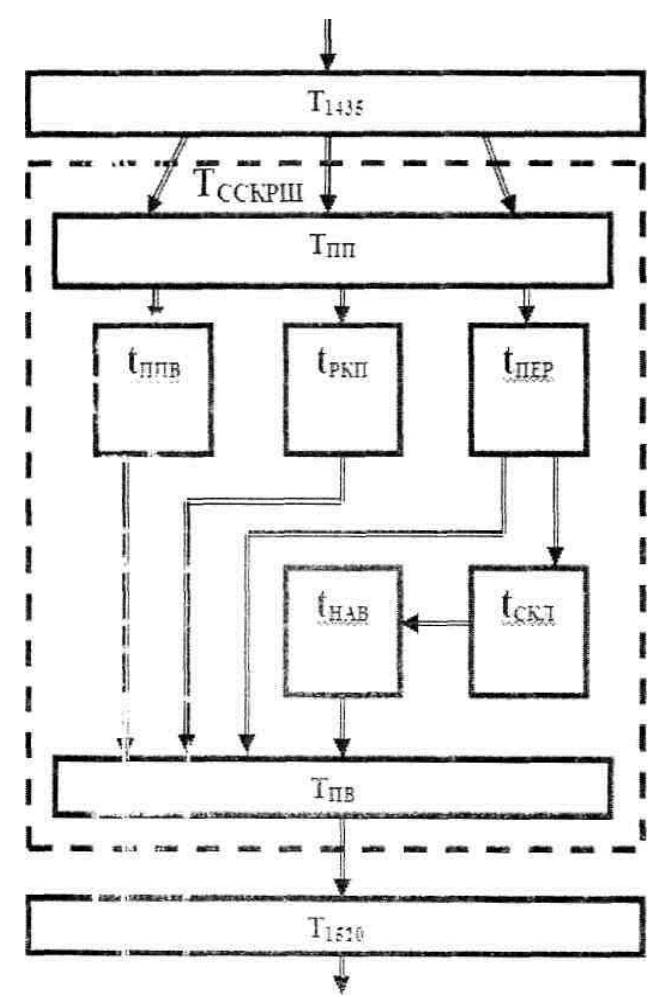

Якщо припустити, що у складі поїзда $\epsilon$ вагони, які підлягають обробці згідно 3 означеними технологіями, то схема розгалуження часових елементів логістичного ланцюга доставки вантажів міжнародного призначення при їх обробці на ССКРШ буде мати такий вигляд (рис. 3).

Рис. 3. Схема розгалуження часових елементів логістичного ланцюга доставки вантажів міжнародного призначення при їх обробці на ССКРШ

Дана схема розроблена для випадку, коли вантажі прибувають на станцію у вагонах колії 1435 мм, а відправляються у вагонах колії 1520 мм.
Згідно 3 даною схемою сумарний час перебування вантажних вагонів на станції стикування колій різної ширини складатиметься з таких елементів:

$$
\begin{aligned}
& \sum_{1}^{s} \boldsymbol{t}_{\text {ССКРШ }}=\sum_{1}^{a} \boldsymbol{t}_{\text {ПГП }}+\sum_{1}^{b} \boldsymbol{t}_{\text {СП }}+\alpha \sum_{1}^{f} \boldsymbol{t}_{\text {ППВ }}+\beta \sum_{1}^{q} \boldsymbol{t}_{\text {рки }}+ \\
& +\gamma\left[\eta \sum_{1}^{r} \boldsymbol{t}^{\prime}{ }_{\text {пер }}+\varphi\left(\sum_{1}^{e} \boldsymbol{t}^{\prime \prime}{ }_{\text {пер }}+\sum_{1}^{u} \boldsymbol{t}_{\text {ски }}+\sum_{1}^{y} \boldsymbol{t}_{\text {нав }}\right)\right]+\sum_{1}^{d} \boldsymbol{t}_{\text {ПВ }}
\end{aligned}
$$


де $\sum_{!}^{a} t_{\text {Пп }}$ - сумарний час перебування вагонів з вантажем у парку приймання;

$\sum_{!}^{b} t_{C П}$ - сумарний час перебування вагонів 3 вантажем у сортувальному парку; $\sum_{1}^{d} t_{\Pi B}$ - сумарний час перебування вагонів з вантажем у парку відправлення; $\sum_{!}^{f} t_{\text {Ппв }}$ - сумарний час перебування вагонів з вантажем у ППВ;

$\sum_{1}^{q} t_{\text {ркn }}$ - сумарний час перебування вагонів з вантажем ПРКП;

$$
\sum_{1}^{r} t_{n e p}^{\prime}, \sum_{1}^{e} t_{n e p}^{\prime \prime} \text { - сумарний час пере- }
$$

вантаження вантажів відповідно у вагони іншої колії або на склад;

$\sum_{1}^{u} t_{c \kappa l}$ - сумарний час перебування вантажу на складі;

$$
\sum_{1}^{y} t_{\text {нав }} \text { - сумарний час перевантаження }
$$

вантажу із складу у вагони.

Кожен состав пропонується розглядати як сукупність вагонів трьох типів:

- вагони, у яких виконується заміна візків колії 1435 мм на візки колії 1520 мм (їх частка складає $\alpha$ );

- вагони 3 розсувними колісними парами $(\beta)$;

- вагони, 3 яких вантажі перевантажуються у вагони колії іншої ширини на тих чи інших фронтах залежно від роду вантажів $(\gamma)$.

Параметри $\alpha, \beta$, та $\gamma$ розглядаються як керуючі параметри, що дозволяють оцінити роботу ППВ, ПРКП та ППер.

Такі ланки логістичного ланцюга, як $\sum_{1}^{r} t_{n e p}^{\prime}, \quad \sum_{1}^{e} t_{n e p}^{\prime \prime}, \quad \sum_{1}^{y} t_{\text {нав }}$, складаються 3 комплексу операцій, що виконуються під час перевантаження вантажу 3 вагона у вагон, з вагона на склад або зі складу у вагон. Вони залежать від типу, кількості та продуктивності НРМ, типу та обсягів вантажів, що перевантажуються, типу складів та рухомого складу, чисельності штату причетних робітників, прийнятої технології та ін. Складові цього елемента поділяються на основні (пересування вантажу, штабелювання і т. д.) та додаткові (стропування, розстановка у вагоні тощо). $\sum_{1}^{u} t_{c \kappa l}$ залежить від типу вантажу, умов зберігання, а також причин, які викликали складування, i складається 3 операцій, пов'язаних із забезпеченням збереженості вантажу. Такий елемент, як $\sum_{1}^{b} t_{C \Pi}$, характеризується витратами часу на насув та розпуск состава, ліквідацію "вікон", осаджування, виконання маневрових рейсів 3 перестановки на перевантажувальні фронти тощо та залежить від швидкості виконання цих процесів, кількості відчепів у составі, кількості сортувальних колій, довжини маневрових рейсів та маневрових валок, кількості маневрових локомотивів, технології виконання робіт і т.д. Елемент $\sum_{1}^{d} t_{\Pi в}$ враховує витрати часу на підформовування состава згідно з планом формування та вимог Правил технічної експлуатації, проведення технічного, комерційного та прикордонного огляду, виконання митних операцій, огляду представниками сусідньої держави, проведення різних видів державного контролю згідно з прийнятою технологією та чинною документацією, операцій 3 документами, заміни маневрового локомотива на поїзний, приготування маршруту відправлення тощо.

У формулу (2) як окремі елементи можуть входити витрати часу на маневрові пересування між станційними пристроями. Вони залежать від типу маневрового локомотива, кількості вагонів у маневровому составі, довжини рейсів та напіврейсів, швидкості руху тощо та обумовлюються конкретними місцевими умовами. 
Висновок. Аналіз існуючих способів передавання вантажних вагонів 3 колії ширини 1435 мм на колію ширини 1520 мм та у зворотному напрямку показав, що кожен 3 них має свої недоліки та переваги, а остаточне рішення про застосування тієї чи іншої технології потребує формалізації транспортних процесів на прикордонних станціях. Складена схема розгалуження часових елементів логістичного ланцюга доставки вантажів міжнародного призначення при їх обробці на станціях стикування колій різної ширини дозволила проаналізувати роботу окремих іiі елементів 3 метою виявлення реальних резервів часу, за рахунок яких можливо скоротити простої вагонів 3 експортно-імпортними вантажами.

\section{Список літератури}

1. Сувальский, P.M. SUW-2000 - новое решение для железнодорожных сообщений [Текст] / Р.М. Сувальский, Ю.В. Демин // Железнодорожный транспорт. - 2003. - № 6 (33). C. 24-27.

2. Кузьменко, А.І. Удосконалення технології перевезення вантажів у міжнародному сполученні [Текст] / А.І. Кузьменко // Вісник Академії митної служби України. Дніпропетровськ: АМСУ, 2008. - № 2 (38). - С. 77-82.

3. Литвиненко, В.П. Разработка методов рациональной транспортировки и перегрузки грузов [Текст] / В.П. Литвиненко, В.А. Ковалев // Залізничний транспорт України. - 2003. № 5. - C. 44 .

Ключові слова: вагонопотік, прикордонні станції, технологія роботи при стикуванні колій різної ширини.

\section{Анотації}

Робота містить процедуру формалізації процесів декомпозиції вхідного вагонопотоку в умовах роботи прикордонної станції. Декомпозиція проводиться у трьох можливих випадках:

- зміна візків;

- перевантаження вантажів;

- SUW - 2000.

Работа содержит процедуру формализации процессов декомпозиции входящего вагонопотока в условиях работы пограничной станции. Декомпозиция проводится в трех возможных случаях:

- изменение тележек;

- перегрузка грузов;

- SUW - 2000.

The work includes formalization of the decomposition process incoming car traffic in terms of border stations. Decomposition is carried out in three possible cases:

- change of cars;

- cargo handling;

- SUW - 2000. 